\title{
Toward a Fuller Understanding of Religious Exercise: Recognizing the Identity- Generative and Expressive Nature of Religious Devotion
}

\author{
David B. Salmons $\dagger$
}

With the recent enactment of the Religious Freedom Restoration Act of 1993 ("RFRA"), ${ }^{1}$ which essentially overruled the Supreme Court's decision in Employment Division, Department of Human Resources of Oregon $v$ Smith, ${ }^{2}$ much attention has been focused on the appropriate level of scrutiny for evaluating Free Exercise Clause claims. Prior to the Smith decision, cases such as Sherbert $v$ Verner ${ }^{3}$ and Wisconsin $v$ Yoder $^{4}$ seemed to make clear that laws adversely affecting religious practices were subject to a standard of strict judicial scrutiny, at least as they applied to the religious practices so affected. Smith, however, rejected the compelling state interest standard of Sherbert and Yoder for the vast majority of free exercise claims-those involving the application of a facially neutral law. In fact, under the Smith majority's formulation, such incidental infringements on religious liberty do not even give rise to a free exercise claim. The response to the Smith decision, particularly Justice Scalia's characterization of prior case law, has been overwhelmingly critical, ${ }^{5}$ with a few notable exceptions, ${ }^{6}$ and is epitomized by Congress's attempt to restore the pre-Smith case law through RFRA.

Unfortunately, many advocates of RFRA and of a return to the pre-Smith compelling state interest approach are as guilty of

$\dagger$ B.A. 1993, Brigham Young University; J.D. Candidate 1996, The University of Chicago.

1 Pub L No 103-141, 107 Stat 1488 (1993), codified at 42 USC $\S 2000 \mathrm{bb}$ (Supp 1993).

2494 US $872(1990)$.

374 US 398 (1963).

406 US 205 (1972).

"For a list of some of the scholarly criticism of Smith, see James E. Ryan, Smith and the Religious Freedom Restoration Act: An Iconoclastic Assessment, 78 Va L Rev 1407, 1409 n 15 (1992).

${ }^{6}$ See, for example, William P. Marshall, In Defense of Smith and Free Exercise Revisionism, 58 U Chi L Rev 308 (1991); William P. Marshall, The Cases Against the Constitutionally Compelled Free Exercise Exemption, 40 Case W Res L Rev 357 (1989-90); Mark Tushnet, The Rhetoric of Free Exercise Discourse, 1993 BYU L Rev 117. 
mischaracterizing precedent as was the majority in Smith. Any candid review of the Court's free exercise jurisprudence leading up to Smith leaves one with the impression that no clear and consistently applied standard existed. ${ }^{7}$ In far too many cases claiming to apply heightened scrutiny to laws infringing on religious practices, particularly those of religious minorities with practices outside of the mainstream Judeo-Christian tradition, the Court did little more than pay lip service to its compelling state interest standard; ${ }^{8}$ indeed, at times it did not even do that. ${ }^{9}$ If anything stands out from the decades of case law applying the potentially sweeping language of the Sherbert-Yoder standard, it is that religious minorities almost always lost. ${ }^{10}$

This Comment argues that the vast majority of commentary debating the appropriate level of scrutiny to apply to religious claims has, in an important respect, missed the point. The central flaw in the Court's free exercise jurisprudence is much deeper than, and is antecedent to, its choice of scrutiny level or balancing test and is therefore not resolved by RFRA. Although RFRA restores the heightened scrutiny framework to free exercise claims, it neither resolves nor addresses this more fundamental error: an incomplete understanding of what religious exercise entails, particularly for less conventional minority religions.

The Court's current conception of the free exercise right is incomplete because it fails to account adequately for the fundamental role religious practice often plays in defining and, more importantly, expressing individual and group conceptions of

7 In Smith, the majority noted that the Court's application of Sherbert's compelling state interest standard in religion cases had not been consistent. 494 US at 882-89. For a thorough review of the Court's jurisprudence in this area, see Ryan, 78 Va L Rev at 141316 (cited in note 5).

${ }^{8}$ See text accompanying notes 17-23.

- For cases refusing to apply a compelling state interest standard to free exercise claims, see Goldman $v$ Weinberger, 475 US 503, 506-10 (1986) (deferring to military determination banning wearing of yarmulkes by servicemen); Lyng $v$ Northwest Indian Cemetery Protective Ass'n, 485 US 439, 450-51 (1988) (building road over sacred areas did not burden religious beliefs); O'Lone $v$ Estate of Shabazz, 482 US 342, 348-50 (1987) (sustaining a prison's refusal to excuse inmates from work requirements to attend worship services); Bowen v Roy, 476 US 693, 699-701 (1986) (requiring disclosure of a Social Security number for welfare benefits did not burden religious beliefs); Alamo Foundation $v$ Secretary of Labor, 471 US 290, 303-06 (1985) (imposing a minimum wage requirement does not burden religious believers who refuse, for religious reasons, to accept wages).

${ }_{10}$ The scorecard for religious claimants under the Sherbert-Yoder compelling state interest standard is telling. See Ryan, $78 \mathrm{Va} \mathrm{L}$ Rev at 1413-17, 1458-62 (cited in note 5) (stating that in the Supreme Court free exercise claims have lost in thirteen of seventeen cases, and in the circuit courts they have lost in eighty-five of ninety-seven cases). 
identity. Consequently, whatever analytic framework the Court employs to balance state interests and religious freedom, be it strict scrutiny or rational basis review, the results are too frequently skewed in favor of the state. Thus, it is the Court's point of initiation rather than its method of operation that leads it to systematically undervalue religious liberty. Accordingly, a stricter balancing test is simply not sufficient; what is needed is a fuller vision of what religious exercise often means to those engaged in it-one that takes into account the deeply symbolic and expressive nature of religious practices and the fundamental and defining role such worship plays in shaping human identity.

Filling in this incomplete understanding of religious exercise requires a more systematic method of articulating the injury an individual sustains when her free exercise rights are infringed. In finding the basis for such a fuller understanding, proponents of a stronger Free Exercise Clause could learn something from a rather unlikely source: sexual orientation theorists.

Recent developments in sexual orientation legal theory, specifically the concept of "identity speech," might help establish a theoretical framework for a fuller vision of the free exercise right. The theory of identity speech combines two powerful aspects of sexual orientation arguments: the fundamental role sexual orientation plays in defining identity; and the expressive nature of the "conduct" involved. Publicly expressing one's status or membership in a class or group that is central to one's identity, even if that expression takes the form of openly engaging in the activities that define the group in question, is at the core of political speech. Indeed, the argument goes, such self-identifying expression should be the most protected form of speech because prohibiting it does the most damage to the individual.

Thus, in arguing for a fuller understanding of religious exercise, this Comment explores the parallels between religion and sexual orientation and identifies developments in sexual orientation legal theory that might contribute to a more complete vision of the free exercise right. Section I traces the development of the Court's free exercise jurisprudence to illustrate the need for a fuller understanding of religious exercise. Section II examines the parallels between religion and sexual orientation, focusing on both individual and group characteristics. Section III develops recent trends in sexual orientation legal theory, focusing on First Amendment challenges to laws and official policies restricting gay and lesbian "conduct." Lastly, Section IV examines the effects of applying the "identity speech" concept in free 
exercise jurisprudence. It concludes that such an application illustrates the errors in judicial approaches to religious claims and provides a broader and more equal protection to religious claimants, particularly religious minorities.

\section{STATUS OF FrEe EXERCISE JURISPRUDENCE}

\section{A. Development of Free Exercise Doctrine before Smith}

In its earliest application, the Free Exercise Clause proved but a parchment barrier to statutes codifying massive hostility against religious minorities. In Reynolds $v$ United States, for example, the Supreme Court held that Congress could impose criminal sanctions against the Mormon practice of plural marriage. ${ }^{11}$ In so deciding, the Court relied on a perceived distinction between religious belief and conduct, stating that "[1]aws are made for the government of actions, and while they cannot interfere with mere religious belief and opinions, they may with practices." ${ }^{12}$

Such an artificial distinction between religious belief and practice fails to recognize that for many believers religion is as much a matter of conduct as of belief. Often the two simply cannot be disentangled. Because the free speech provision of the First Amendment already protects freedom of belief, whether secular or religious, a reading of the Free Exercise Clause that does not protect at least some religiously based conduct offensive to the majority's sensibilities leaves that provision devoid of any practical consequence. Such an interpretation is particularly untenable when one considers that it is the religious practices of unpopular minorities that the state is most likely to restrict and are therefore the most in need of protection.

However, the Court gradually retreated from this constricted interpretation of the Free Exercise Clause. In Cantwell $v$ Connecticut, it announced that the free exercise right was not limited to protection of belief but extended to the "freedom to act," although to a significantly lesser degree. ${ }^{13}$ According to the Court,

1198 US 145 (1878).

12 Id at 166. The opinion also relies on the assertion that "polygamy leads to the patriarchal principle, and ... when applied to large communities, fetters the people in stationary despotism." Id. Justice Souter's concurring opinion in Church of Lukumi Babalu Aye, Inc. $v$ City of Hialeah, 113 S Ct 2217, 2245-47 (1993), asserts that Reynolds may still be valid, since the state's interest so framed meets the Sherbert-Yoder test.

13310 US 296, 303-04 (1940). Cantwell is also notable as the opinion that "incorporated" the Free Exercise Clause into the Due Process Clause of the Fourteenth Amendment, 
freedom of belief was "absolute," while conduct could be regulated "for the protection of society" so long as the state did not "unduly [ ] infringe the protected freedom." ${ }^{14}$

The high-water mark of free exercise protection came with the Supreme Court's decisions in Sherbert in 1963 and Yoder in 1972. With these decisions, the Court seemed to make clear that the Free Exercise Clause did have a protective sphere of its own that extended beyond that of other First Amendment freedoms. In Sherbert, the Court held that the Free Exercise Clause compelled South Carolina to grant unemployment benefits to a Seventh Day Adventist unable to find employment because she refused to work on her Sabbath. Applying a test that involved both the "compelling state interest" and "least restrictive alternative" standards, the Court concluded that even an "incidental burden on the free exercise of appellant's religion may be justified [only] by a 'compelling state interest."'15

Applying a similar analysis, the Court in Yoder held that Wisconsin's facially neutral, generally applicable law requiring compulsory school attendance for all children under age sixteen violated the free exercise rights of Amish families. According to the Court, "[t]he essence of all that has been said and written on the subject is that only those interests of the highest order and those not otherwise served can overbalance legitimate claims to the free exercise of religion." ${ }^{36}$

However, of the various free exercise cases arising after Yoder in which courts applied the potentially sweeping language of the Sherbert-Yoder test, remarkably few resulted in victories for religious claimants, particularly religious minorities. ${ }^{17}$ Using the highly manipulable balancing test Sherbert and Yoder established for free exercise jurisprudence ${ }^{18}$ courts repeatedly exaggerated the weight of the governmental interest by speculating about a parade of horribles that would follow a decision adverse to that interest, excessively worrying about the ability to detect feigned religious devotion, and defining the state's interests at a higher level of generality than the constitutional interests on the other side of the balance. Thus, while claiming that only interests

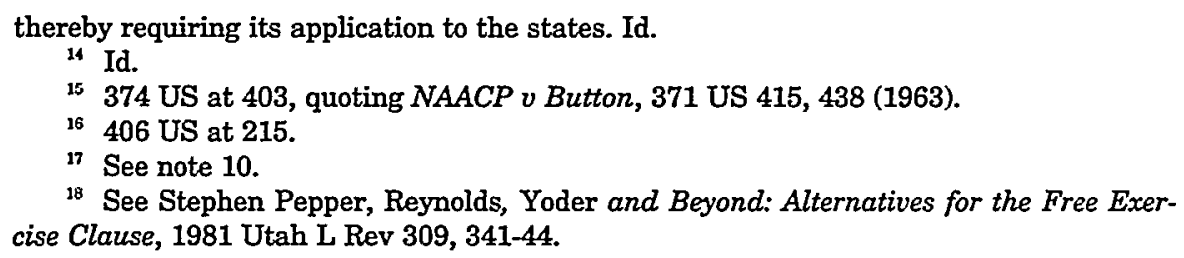

${ }^{18}$ See Stephen Pepper, Reynolds, Yoder and Beyond: Alternatives for the Free Exercise Clause, 1981 Utah L Rev 309, 341-44. 
of the "highest order"19 could justify a burden on religious liberty, the Court upheld state regulations that were justified by such interests as the uniform application of laws and administrative convenience. ${ }^{20}$ As several observers have noted, the Court's acceptance of such relatively flimsy state justifications indicates that it was not applying a genuine "compelling" interest test. ${ }^{21}$

Perhaps the best example of the Court overstating the government's interest while systematically understating the scope and centrality of religious exercise is Prince $v$ Massachusetts. ${ }^{22}$ In upholding the conviction of a Jehovah's Witness for violating child labor laws by taking her teenage niece out proselytizing on the public streets of their small town, the Court placed on the government's side of the balance "the interest of youth itself, and of the whole community, that children be [ ] safeguarded from abuses and given opportunity for growth" and protected from the "crippling effects of child employment," even though few if any of the evils typically associated with child labor were present. ${ }^{23}$ No such inflation was made on the individual free exercise side of the balance. Indeed, the Court failed even to recognize the central and defining role proselytizing plays in the way in which a Jehovah's Witness worships her God.

In addition to manipulating the balancing test by relaxing the compelling interest standard, courts have simultaneously heightened the level of burden necessary to state a free exercise claim. Before a free exercise claim can be examined under the compelling interest standard, the claimant must show that her religious beliefs or practices have actually been burdened. Often, this is no easy task. In Lyng $v$ Northwest Indian Cemetery Protective Ass'n, the Supreme Court held that no constitutionally recognizable burden on Indian religion resulted from the building of a

19 Yoder, 406 US at 215.

20 See, for example, Bowen v Roy, 476 US 693, 707 (1986) (citing administrative concerns in rejecting free exercise challenge to federal regulation that required welfare recipients to provide Social Security numbers); United States $v$ Lee, 455 US 252, 258 (1982) (ruling that the federal government has a compelling interest in the uniform application of the Social Security system).

${ }_{21}$ See, for example, Michael W. McConnell, Free Exercise Revisionism and the Smith Decision, 57 U Chi L Rev 1109, 1110 (1990) (“[A]t the Supreme Court level, the free exercise compelling interest test was a Potemkin doctrine."); Ryan, 78 Va L Rev at 141316 (cited in note 5) (reviewing the poor record of free exercise claimants before the Supreme Court). See also EEOC v Townley Engineering and Manufacturing Co., 859 F2d 610, 624 (9th Cir 1988) (Noonan dissenting) (expressing regret over the Supreme Court's failure to apply genuine strict scrutiny analysis to religious claims).

22321 US 158 (1944).

${ }^{23}$ Id at 165,168 (citations omitted). 
road through a Native American sacred site. ${ }^{24}$ Writing for the majority, Justice O'Connor reasoned that a constitutionally recognizable burden on religion can only exist if the government action has a "tendency to coerce individuals into acting contrary to their religious beliefs." 25 This was so even though the government action in question "could have devastating effects on traditional Indian religious practices." ${ }^{26}$ Thus, courts rarely recognize government actions that make religious exercise more expensive or inconvenient, ${ }^{27}$ or that do not force the claimant to forego an "important" benefit, ${ }^{28}$ as burdens sufficient to warrant compelling interest review.

In other cases involving Native American challenges to the use of publicly owned sacred land sites, courts have added to the burden inquiry the additional element that the particular site be "central" or "indispensable" to the claimants' religious practices. ${ }^{29}$ In Sequoyah $v$ Tennessee Valley Authority, for example, the Sixth Circuit held that the flooding of Cherokee holy places, ancestral burial grounds, and ceremonial medicine gathering sites did not sufficiently burden the free exercise rights of the Native American claimants to warrant judicial scrutiny absent a showing that the particular valley to be flooded was "indispensable" to their religious practices. ${ }^{30}$ Furthermore, in Wilson $v$ Block, the D.C. Circuit defined "indispensable" to mean that unless the Native American claimants could show that the government's proposed land use "would impair a religious prac-

24485 US 439 (1988).

25 Id at 450.

26 Id at 451 .

${ }^{27}$ See, for example, Messiah Baptist Church $v$ County of Jefferson, 859 F2d 820, 82426 (10th Cir 1988) (holding that because zoning laws that made the claimants' religious practices "more expensive" did not place an "undue burden" on their free exercise rights, compelling interest analysis was not required); Smith $v$ North Babylon Union Free School District, 844 F2d 90, 94 (2d Cir 1988) (rejecting the claim of an orthodox Jewish student who objected to the holding of graduation ceremonies on Saturday, his Sabbath, and stating that state action that "simply makes the practice of his religion more difficult than the practice of other religions ... is not the type of burden on core religious freedom rising to the level of a violation of the free exercise clause").

${ }_{28}$ See, for example, Smith, 844 F2d at 93.

${ }^{22}$ For a discussion of the judicial treatment of Native American religious claims, particularly the additional burden requirements of centrality and indispensability, see Comment, After the Religious Freedom Restoration Act: Still No Equal Protection for First American Worshipers, 24 NM L Rev 331, 335-42 (1994).

${ }^{30} 620$ F2d 1159 (6th Cir 1980). In order for relief to be granted, the court required a showing that worship at the particular site in question was "the cornerstone of [Native Americanl religious observance" or that it played "the central role in their religious ceremonies and practices." Id at 1164. 
tice that could not be performed at any other site," they failed to raise a First Amendment claim. Because no free exercise claim was recognized, the court did not even inquire into the government's interest in developing the land. ${ }^{31}$

Regardless of one's views on the merits of these cases, one must recognize that courts have clearly manipulated the burden requirement to reach particular results. When combined with a loose application of the compelling interest standard, this judicial manipulation leaves religious claimants, particularly religious minorities, in a rather unenviable position. In order to establish a burden, religious claimants must show that the government involvement or interference with their religious practices is intrusive enough to potentially coerce them into violating their faith. Yet given what often passes for "compelling" interests in these cases, the mere existence of such extensive regulation could signify that the government has a sufficient interest in the law or practice in question. ${ }^{32}$ In practice, then, demonstrating "coercive" regulation only adds to the government's claim of compelling interest. Conversely, less coercive government action, although indicative of a lesser governmental interest, makes it unlikely that the burden inquiry will be satisfied. Thus, for the religious claimant, to satisfy one requirement is often to demonstrate failure of the other. ${ }^{33}$ It is therefore not surprising that most free exercise plaintiffs, and virtually all religious minorities, find themselves on the lighter end of the judicial balance even though it is purportedly tilted in their favor.

\section{B. Smith and the Religious Freedom Restoration Act}

Whatever one makes of the stingy application of the compelling state interest test under Sherbert and Yoder, the Supreme Court's decision in Employment Division, Department of Human Resources of Oregon $v$ Smith marked a significant shift in free exercise jurisprudence. Although the parties in Smith neither questioned nor argued the validity of the Sherbert-Yoder test, the Court abruptly and unexpectedly denied that it had ever existed, and appears to have returned to a reading of the Free Exercise

31708 F2d 735, 743-45 (DC Cir 1983).

${ }^{32}$ See, for example, Townley, 859 F2d at 624 (Noonan dissenting) (stating that the mere fact that Congress has chosen to address a problem through federal legislation has often been construed as sufficient evidence of a compelling interest).

${ }^{33}$ For a discussion of this "catch-22," see Ryan, 78 Va L Rev at 1416 (cited in note 5). 
Clause similar to that adopted in Reynolds. ${ }^{34}$ In upholding the denial of unemployment compensation to members of the Native American Church who were discharged for admitting their use of peyote during a religious ceremony, Justice Scalia, writing for the five-member majority, asserted that the Court had "never held that an individual's religious beliefs excuse him from compliance with an otherwise valid law prohibiting conduct that the State is free to regulate. ${ }^{335}$

Under the majority's view, as long as legislatures discipline themselves through the equality principle-passing only generally applicable laws not facially singling out religion generally or any particular religion-they must be permitted to act and legislate in an across-the-board fashion. ${ }^{36}$ Furthermore, the democratic process will protect the interests of religious minorities. ${ }^{37}$ As Justice Scalia noted, "a number of States have made an exception to their drug laws for sacramental peyote use. ${ }^{38}$ The implicit assurance was that Oregon would likely follow suit once the press had publicized the plight of the Native American Church membership. ${ }^{39}$

Perhaps most disturbing was the Court's treatment of twenty-five years of case law applying the Sherbert-Yoder standard. According to the majority, "[t]he only decisions in which we have held that the First Amendment bars application of a neutral, generally applicable law to religiously motivated action have involved not the Free Exercise Clause alone, but the Free Exercise Clause in conjunction with other constitutional protections, such as freedom of speech and of the press, or the right of parents to direct the education of their children." ${ }^{30}$ Thus, under Smith's "free exercise plus" standard, strict scrutiny applies only when religious practices commingle with another independently

34 See text accompanying notes 11-12.

35 Smith, 494 US at 878-79. Justice O'Connor authored a concurring opinion arguing that the compelling state interest test was the appropriate standard but that the state's interest in fighting the war on drugs sufficiently met this burden. Id at 905-07. Justice Blackmun, joined by Justices Brennan and Marshall, dissented, agreeing with Justice O'Connor that the compelling state interest test should be applied but concluding that the state had failed to make such a showing. Id at 907-09, 918.

36 Id at 879-82.

37 The majority apparently forgot the days when the Oregon state legislature decided, in a fit of anti-Catholic fervor, to effectively abolish all parochial schools through generally applicable legislation. See Pierce $v$ Society of Sisters, 268 US 510 (1925).

33 Smith, 494 US at 890.

39 Indeed, Oregon has since enacted an exemption for the sacramental use of peyote. See Or Rev Stat § $475.992(5)$ (1993).

${ }^{40}$ Smith, 494 US at 881 (citations omitted). 
protected right; an infringement on religious exercise by an otherwise general law standing alone is simply not sufficient to warrant heightened judicial scrutiny.

It is now clear that Smith will not be the Court's last word on this issue. President Clinton has recently signed the Religious Freedom Restoration Act into law, which passed both houses of Congress by overwhelming margins. ${ }^{41}$ RFRA represents the political rejection of the Supreme Court's interpretation of the scope of the free exercise right in Smith. Essentially, it seeks to restore the status quo ante Smith by requiring that a government action may substantially burden an individual's exercise of religion only if the government demonstrates that the action furthers a compelling state interest and is the least restrictive means of furthering that interest.

There are many aspects and implications of RFRA that merit attention, most of which are beyond the scope of this Comment. ${ }^{42}$ The important point here is that although RFRA requires a compelling state interest to justify a government action that "substantially burdens" an individual's free exercise right, it does not resolve the Court's incomplete conception of religious exercise itself. There is nothing in RFRA that changes, or even addresses, the ingrained judicial misconceptions of minority religions discussed above. In fact, the Senate Judiciary Committee specifically stated that it expected "that the courts will look to free exercise cases decided prior to Smith for guidance in determining whether the exercise of religion has been substantially burdened and the least restrictive means have been employed in furthering a compelling governmental interest." ${ }^{\text {"3 }}$ Thus, RFRA provides no additional guidance for avoiding the two main points of judicial manipulation prior to Smith, namely, what constitutes a "compelling" state interest and how one determines whether a

41 See 139 Cong Rec H2363 (May 11, 1993); 139 Cong Rec S14471 (Oct 27, 1993).

42 These include questions of constitutionality, legislative intent, and statutory interpretation, as well as more general inquiries into the comparative advantages of courts and legislatures as protectors of religious liberties.

For a fuller discussion of RFRA, see Rex E. Lee, The Religious Freedom Restoration Act: Legislative Choice and Judicial Review, 1993 BYU L Rev 73 (discussing the merits and constitutionality of RFRA); Ryan, $78 \mathrm{Va} L$ Rev at 1437-44 (cited in note 5) (arguing that RFRA, although constitutional, is ineffective, is bad policy, and might even hurt religious minorities); Allan Ides, The Text of the Free Exercise Clause as a Measure of Employment Division v. Smith and the Religious Freedom Restoration Act, 51 Wash \& Lee L Rev 135, 151-55 (1994) (concluding that neither Smith nor RFRA is adequately tied to a textual interpretation of the Free Exercise Clause).

${ }^{43}$ S Rep No 103-111, 103d Cong, 1st Sess 8-9 (1993). See also 139 Cong Rec S6464 (May 25, 1993) (statement of Sen Wellstone). 
religious exercise has been "substantially burdened." As a result, RFRA does nothing to resolve the current judicial failure to adequately recognize and respect the core role religious practice plays in shaping and expressing conceptions of identity.

\section{The Nature of the Court's Misconception of Religious Exercise}

Exposing the manipulability of the Court's free exercise doctrines raises the question of why courts so frequently weighted the balance to virtually ensure that religious claimants, particularly religious minorities with unconventional practices, would lose. Although no single explanation is dispositive, several possibilities provide a partial response. These include a "floodgates" fear that a plethora of future, often unfounded, claims await judicial decision makers once the accomodation process begins, coupled with a perceived difficulty in distinguishing between meritorious and fraudulent free exercise claims, ${ }^{44}$ and a recognition that while a few exemptions from a particular law might not threaten the state's ability to achieve its legitimate goals, a large number of exemptions pose just such a threat. ${ }^{45}$

There is good evidence that these judicial fears are largely unfounded. First, it is not uncommon for religious claimants, finding their exemption request rejected by courts, to gain subsequently the same exemption from the legislature. ${ }^{46}$ Significantly, none of these exemptions has led to the type of "floodgates" problems anticipated by the courts. ${ }^{47}$ Second, as several commentators have noted, if a great many potential claimants were likely to seek exemptions from a particular law, it is highly unlikely that such a law would pass in the first place. ${ }^{48}$ Thus, allowing religious exemptions is unlikely to undermine substantially the effectiveness of government policy-making.

4 See, for example, Goldman $v$ Weinberger, 475 US 503, 510-13 (1986) (Stevens concurring) (arguing that possible future and extreme claims for religious exemptions from military dress code justified the denial of the more reasonable claim before the Court).

45 Justice Scalia's fear in Smith regarding individuals becoming "a law unto themselves" is illustrative of this point. See 494 US at 885.

46 For a general review of legislative exemptions, see Ryan, $78 \mathrm{Va} \mathrm{L} \mathrm{Rev} \mathrm{at} \mathrm{1445-55}$ (cited in note 5). The Court's rejection of a Jewish serviceman's claim for an exemption from the military's dress code to allow the wearing of a yarmulke in Goldman, 475 US 503 , and its subsequent overturning by Congress provide a most enlightening example. See text accompanying notes 100-09.

${ }^{47}$ Again, Goldman is illuminating. See text accompanying notes 107-09.

4S See McConnell, 57 U Chi L Rev at 1147-48 (cited in note 21). See also Stephen Pepper, Taking the Free Exercise Clause Seriously, 1986 BYU L Rev 299, 313-15. 
Although not as easy to identify, another potential explanation must be considered. Whether the result of cultural insensitivity, bias, or some more benign factor, courts have adopted a narrow conception of religious exercise that often fails to account for the fundamental role religious practice plays in developing and expressing individual and group conceptions of identity and that even more frequently fails to provide minority religions with the same degree of protection enjoyed by mainstream Christianity. In other words, they underestimate the importance of the religious practice to the individual or group affected, particularly if those practices are outside of the mainstream Judeo-Christian tradition. This incomplete understanding of religious exercise manifests itself in several ways. First, courts are skeptical toward claims involving unconventional religious practices. In the Native American sacred site cases, for example, requiring a showing of "indispensability" demonstrates a judicial failure to appreciate the role sacred land sites play in Native American worship practices and, more importantly for the present analysis, in shaping and expressing Native American religious identity.

The Sixth Circuit's opinion in Sequoyah is a particularly good example of the judiciary's failure to account for the identitygenerative and expressive functions of Native American religious practices. ${ }^{49}$ In rejecting a challenge to the flooding of government-owned sacred sites, the court stated:

The claim of centrality of the Valley to the practice of the traditional Cherokee religion ... is missing from this case. The overwhelming concern of the affiants appears to be related to the historical beginnings of the Cherokees and their cultural development. It is damage to tribal and family folklore and traditions, more than particular religious observances, which appears to be at stake:... [T]hese are not interests protected by the Free Exercise Clause of the First Amendment. ${ }^{50}$

One is left wondering with whose "particular religious observances" the court was comparing the Cherokee practices.

Both the court's cultural bias and its incomplete understanding of the diversity and depth of religious exercise appear in its relegation to the status of mere "folklore" what to the claimants lay at the very core of their worship practices. Ironically, what

\footnotetext{
49 For the facts of Sequoyah, see text accompanying note 30 .

so 620 F2d at 1164-65 (emphasis added).
} 
the court dismissed as folklore and tradition, and left unprotected by the Free Exercise Clause, may in fact be the critical element not only of Native American worship, but of the ability of Native Americans to develop, express, and perpetuate their distinctive religious identity. ${ }^{51}$ Any conception of religious exercise that discounts practices so central to individual and group religious identity is woefully incomplete and is tantamount to the establishment of state orthodoxy considered anathema by the Supreme Court. $^{52}$

This incomplete understanding of religious exercise helps explain not only why so many claims of religious minorities were rejected by the courts but also why the claims of others were so successful. Unquestionably, the single most successful class of free exercise cases has been unemployment compensation claims. ${ }^{53}$ Indeed, as Justice Scalia noted in Smith, unemployment compensation has been the only area in which the Court has consistently applied anything that resembles a genuine compelling state interest standard. ${ }^{54}$ Although the importance of the benefit at stake and the absence of any apparent state interests in denying the benefits offer a partial explanation, unemployment compensation claims have had unparalleled success in part because there is clear evidence of the centrality and significance of the religious practice in question. Simply put, it is difficult to question the centrality of a claimant's beliefs when she is willing to sacrifice her profession and livelihood rather than compromise her devotion. Because other claims do not provide such unequivocal evidence of the important role that the practice plays for the individual, members of religious minorities who assert them rarely prevail.

The Court's flawed and incomplete understanding of religious exercise, which underlies much of its free exercise jurisprudence, rose to the surface in Smith. As if the devaluation of religious rights implied by the majority's "free exercise plus" standard ${ }^{55}$

51 See Comment, 24 NM L Rev at 338 (cited in note 29).

52 See West Virginia State Board of Education v Barnette, 319 US 624, 642 (1943) ("If there is any fixed star in our constitutional constellation, it is that no official, high or petty, can prescribe what shall be orthodox in politics, nationalism, religion, or other matters of opinion.").

${ }_{53}$ See, for example, Frazee $v$ Illinois Department of Employment Security, 489 US 829 (1989); Hobbie v Unemployment Appeals Commission, 480 US 136 (1987); Thomas $v$ Review Board, 450 US 707 (1981); Sherbert, 374 US 398.

st See 494 US at 883-84.

is Recall that Smith protects religious practices from otherwise valid laws only in the "hybrid" cases where religious rights commingle with other protected rights. See text ac- 
was not enough, the Court exposed its narrow characterization of religious exercise even more when it specifically held that the Native American Church's sacramental use of peyote in its religious ceremonies did not "present such a hybrid situation, but a free exercise claim unconnected with any communicative activity. ${ }^{356}$ Amazingly, not a single Justice, not even those in dissent, took issue with the majority's noncommunicative conclusion. Apparently, every Justice on the Supreme Court failed to recognize any expressive or communicative value in the Native American Church's formal sacramental ceremony, an established rite of its worship services that has existed for generations. ${ }^{57}$ Such nonrecognition is particularly surprising when one considers the various other forms of conduct the courts have viewed as potentially possessing expressive value. ${ }^{58}$

Ironically, Justice Scalia, in Barnes $v$ Glen Theatre, Inc., argued that the appropriate definition of "inherently expressive conduct" is activity "that is normally engaged in for the purpose of communicating an idea, or perhaps an emotion, to someone else. ${ }^{359}$ One would be hard pressed to find a better example of "inherently expressive conduct" under Justice Scalia's own standard than a formal religious ceremony such as the one at issue in Smith. Yet in the religion context, the Court characterized the sacramental peyote ceremony as lacking any communicative value. ${ }^{60}$ Clearly, for members of the Native American Church, the sacramental use of peyote is rich in symbolism and expres-

companying note 40 .

${ }^{56} 494$ US at 882 (emphasis added).

57 However, Justice Souter, in his significant concurring opinion in Church of Lukumi Babalu Aye, Inc. v City of Hialeah, 113 S Ct 2217, $2244-45$ (1993), rejected what he termed the "hybrid exception" of Smith and specifically noted that "free speech and associational rights are certainly implicated in the peyote-smoking ritual."

${ }^{*}$ See, for example, Barnes $v$ Glen Theatre, Inc., 501 US 560 (1991) (plurality opinion) (accepting that public nude dancing is "expressive conduct"); Texas $v$ Johnson, 491 US 397 - (1989) (flag burning); Tinker v Des Moines Independent Community School District, 393 US 503 (1969) (wearing colored arm bands); United States v O'Brien, 391 US 367, 382 (1968) (assuming that the act of burning a draft card during an antiwar protest had a communicative element in it sufficient to implicate the First Amendment, but allowing conviction for the nonexpressive aspect of the act); Brown $v$ Louisiana, 383 US 131 (1966) (participating in a sit-in); Stromberg $v$ California, 283 US 359 (1931) (flying a red flag). But compare O'Brien, 391 US at 376 (stating that the Court will not "accept the view that an apparently limitless variety of conduct can be labeled 'speech' whenever the person engaging in the conduct intends thereby to express an idea").

${ }^{59} 501$ US 560, 577 n 4 (1991) (Scalia concurring).

${ }^{60}$ One wonders whether a claim regarding the use of communion wine rather than sacramental peyote would equally be treated as a "free exercise claim unconnected with any communicative activity." Smith, 494 US at 882. 
sive content. If nothing else, it is a way in which believers gather together to declare openly their identity as members of the Church, a religion distinguished not only by beliefs, but also by its unique worship practices. That the Supreme Court failed to get the message does not make their religious conduct any less expressive. Having slighted the expressive nature of the religious conduct, the Court equally ignored the devastating effects the prohibition of peyote could have on the formation of individual and group identity within the Native American Church.

Thus, what is needed is not just a stricter balancing test, but a fuller vision of what religious devotion and practice is all about-one that takes into account the richly symbolic and expressive nature of religious practices for those who adhere to them and the fundamental role such worship plays in defining and communicating conceptions of identity. An approach emphasizing these elments might help fill the void created by the Court's current conception of religious exercise. Odd as it perhaps appears, proponents of a more vital Free Exercise Clause might find the foundation of such an approach in the concept of "identity speech" recently developed in the area of sexual orientation legal theory.

\section{Parallels Between Sexual Orientation and Religion}

Before examining these developments in the area of sexual orientation legal theory, this Section explores the relevant parallels between sexual orientation and religion, focusing on both individual and group characteristics. In exploring these parallels, however, care must be given not to overstate the similarities. Important differences between these areas of law exist, most notably in the interaction of the Establishment Clause with free exercise jurisprudence, and in the possible lack of choice in selecting one's sexual orientation-depending on how one views the genetics/environment debate. Important limits on the analogy also stem from the express constitutional source of protection for religion. ${ }^{61}$

The purpose of sketching out the relevant parallels between religion and sexual orientation is not to establish a formal analogy between these diverse areas such that a conclusion reached in

62 Note, however, that arguably the same is true of race, but its grounding in the Reconstruction amendments does not inhibit similar comparisons and analogies. See text accompanying note 85 . 
one must necessarily apply to the other. Rather, it is to provide a background for the conclusion that proponents of a more vibrant Free Exercise Clause should take notice of recent developments in sexual orientation theory. Similar arguments in the religion context might provide a basis for a fuller vision of what religious exercise entails and hence greater protection of religious freedom.

Once the similarities of the claims are recognized, it is easier to understand the possible merits of adapting identity speech concepts to the free exercise arena. Indeed, the value of adapting identity speech arguments to the free exercise realm remains salient, regardless of their eventual success or failure in sexual orientation jurisprudence.

\section{A. Fundamental to Identity}

Perhaps the most important parallel between sexual orientation and religion is the fundamental role both appear to play in shaping an individual's concept of identity and personhood. ${ }^{62}$ When one considers the strength with which claims of religious or sexual preferences are held and their resistance to change by rational discourse or other decision-making processes, one senses that these are matters particularly ill suited for resolution by democratic voting or scientific investigation. As one commentator noted, "[m]ajority rule does not fit well with those kinds of beliefs; compromise does not fit a great deal better; and imposition by legal authority from above on such beliefs is not likely to be taken with equanimity." ${ }^{163}$ Consequently, government incursions into these areas tend to have a more devastating effect on individuals than intrusions on other, less defining areas.

${ }^{62}$ Of course there may be several other classifications or interests, such as "southerner," "Klan member," or "vegetarian," that may also play an important role in shaping identities and yet receive no special constitutional protection. Some substantive, valuative standards are needed to distinguish these nonprotected identity-generative elements from those that warrant protection. However, such an undertaking is beyond the scope of this Comment. Suffice it to note that the existence of other nonprotected identity-generative elements does not bear on the present analysis for at least two reasons. First, this Comment does not argue that religion or sexual orientation should be protected because it is fundamental to human identity, but that courts have not adequately considered religion's fundamental role in shaping identity and that developments in sexual orientation theory may provide the basis for greater protection. Second, as for religion, the explicit protection of the Free Exercise Clause provides the substantive distinction necessary to distinguish it from other elements of identity. For a thorough examination of the distinctive nature of sexual orientation, see Janet E. Halley, Sexual Orientation and the Politics of Biology: A Critique of the Argument from Immutability, 46 Stan L Rev 503, 519-20 (1994).

a Stephen Pepper, Conflicting Paradigms of Religious Freedom: Liberty Versus Equality, 1993 BYU L Rev 7, 39. 
Of course, religion or sexuality is not important to everyone, but then neither is procreation, family life, or other core autonomy concerns. One need not believe in God to acknowledge that for many individuals the role religious beliefs play in their lives is of unparalleled value. The same holds true for sexuality and sexual orientation. Both are intimately involved in many of the core experiences of existence, including marriage, intimacy, and procreation.

However, recognizing the role religion or sexual orientation plays in defining individual identity as a way of distinguishing either from other characteristics, while descriptively accurate, has important practical and normative consequences. In particular, such a recognition singularly implicates issues of equality.

In the area of sexual orientation, equality norms are often seen as cutting against discrimination on the basis of sexual orientation. If gay, lesbian, and bisexual orientations serve the same identity-generative function that heterosexuality does for the majority of individuals, then both formal and substantive equality argue that they be treated in the same way. ${ }^{64}$ Recognition of same-sex marriages and the provision of health care, disability, and other benefits to same-sex spouses are just a few results such equality norms compel..$^{65}$

In the area of religion, however, the equality analysis is more complex. For example, several commentators have argued that exempting religiously motivated conduct from otherwise generally applicable laws while denying exemptions for the same conduct undertaken for other reasons violates the neutrality required by the Constitution. ${ }^{66}$ But, in large part, the determi-

64 Note that this "sameness" argument is by no means uncontroversial. Some view gay and lesbian orientation as unnatural, immoral, or deviant, and therefore not the same as heterosexuality. Others argue that the assumption that sexual orientation is a defining characteristic of personhood depends on and reinforces rigid sexual categories that further the oppression of those defined as different. See Note, Custody Denials to Parents in Same-Sex Relationships: An Equal Protection Analysis, 102 Harv L Rev 617, 622-23 (1989).

. ${ }^{65}$ See, for example, Deborah L. Rhode, Feminism and the State, 107 Harv L Rev 1181, 1198-99 (1994) (arguing that failure to extend to same-sex couples such benefits accompanying marital status as tax, inheritance, insurance, welfare, pension, spousal support, custody, and adoption rights "violate[s] fundamental principles of equal recognition and personal autonomy, penalize[s] egalitarian caretaking relationships, and reinforce[s] . . . gender stereotypes"). For a catalogue of similar state policies and a response to them, see Developments in the Law, Sexual Orientation and the Law, 102 Harv L Rev 1508, 1519-21 (1989).

65 See, for example, Marshall, $58 \mathrm{U}$ Chi L Rev at 319-23 (cited in note 6); Note, Employment Division v. Smith: The Supreme Court Improves the State of Free Exercise Doctrine, 12 SLU Pub L Rev 569 (1993); Christopher L. Eisgruber and Lawrence G. Sager, 
nation of whether a special religious exemption conflicts with equality principles turns on whether we are valuing formal or substantive equality. ${ }^{67}$ Although granting special treatment only to religiously motivated conduct would be a clear violation of formal equality, analysis under substantive equality might yield a very different result. ${ }^{68}$ For the reasons discussed above, the person whose religious life is invaded by a legal provision is not similarly situated to the person for whom the provision has no such effect. ${ }^{69}$ It is an odd equality indeed that insists on ignoring the disparate impact of legal provisions on individuals so differently situated. ${ }^{70}$

Interestingly, for some commentators religion's central role in defining human identity creates a special threat to freedom. According to this view, religious indoctrination causes competing

The Vulnerability of Conscience: The Constitutional Basis for Protecting Religious Conduct, 61 U Chi L Rev 1245, 1254-67 (1994).

67 "Formal" and "substantive" are used here in accord with Justice Souter's concurring opinion in Church of Lukumi Babalu Aye, Inc. v City of Hialeah, 113 S Ct 2217, 2241-42 (1993), which identified "formal neutrality" as barring only laws with an object to discriminate against religion, and "substantive neutrality" as requiring a similar secular object, but in addition providing religious exemptions for practices adversely affected by formally neutral laws. Thus, a primary difference between formal and substantive neutrality is the latter's recognition and protection of substantive religious differences. Id. See also Yoder, 406 US at $235 \mathrm{n}$ 22, quoting Sherbert, 374 US at 409 (stating that a religious exemption to a general law "reflects nothing more than the government obligation of neutrality in the face of religious differences"); Pepper, 1993 BYU L Rev at 49-55 (cited in note 63) (discussing differences between formal and substantive neutrality in the context of free exercise claims). In addition, Justice Souter identifies the Smith decision with formal neutrality and the Sherbert-Yoder doctrine with substantive neutrality and concludes that the latter is a correct interpretation of the Free Exercise Clause. Church of Lukumi Babalu Aye, $113 \mathrm{~S} \mathrm{Ct}$ at 2240-50 (Souter concurring).

\&s See generally Douglas Laycock, Formal, Substantive, and Disaggregated Neutrality Toward Religion, 39 DePaul L Rev 993, 1000-06 (1990) (examining various approaches to neutrality, but concluding that "substantive" neutrality, which seeks to equalize and minimize the disparate impact of government actions on those holding various beliefs, is most consonant with the religion clauses). For an additional distinction between "formal" and "facial" neutrality, see Church of Lukumi Babalu Aye, 113 S Ct at $2242 \mathrm{n} 3$ (Souter concurring).

wo For an interesting analysis of neutrality in the religion context, see Michael W. McConnell and Richard A. Posner, An Economic Approach to Issues of Religious Freedom, $56 \mathrm{U}$ Chi L Rev 1, 35 (1989) (concluding that "a regulation is not neutral in an economic sense if, whatever its normal scope or its intentions, it arbitrarily imposes greater costs on religious than on comparable nonreligious activities").

${ }_{70}$ Moreover, under such an exemption doctrine, most of the purposes of governmental action can still be reached; the exemption typically involves a very small group of believers while the law remains valid for all others. Indeed, if the exemption would be applicable to a substantial minority, it is unlikely the legal provision would have ever been enacted. See Pepper, 1986 BYU L Rev at 313-15 (cited in note 48); McConnell, 57 U Chi L Rev at 1147-48 (cited in note 21 ). 
belief systems to be seen as threats to an individual's sense of self and therefore as something that must be attacked and, if possible, eradicated. ${ }^{71}$ Persecution and intolerance are the inevitable results of adhesion to religious beliefs, regardless of how peaceful and conciliatory the particular beliefs involved. Consequently, rather than accommodating such beliefs, government should enforce formal equality between religious and nonreligious systems. ${ }^{72}$ However, for present purposes, the important point is that regardless of whether one views it as an important element of individual liberty or a dangerous threat to freedom, the central role religion plays in defining human identity is undisputed.

\section{B. Important Element of Conduct}

Another parallel between religion and sexual orientation is that both possess an important behavioral component. This element of conduct distinguishes both areas from other common classifications such as race and gender. Failure on the part of courts, lawmakers, and many advocates to address adequately this behavioral component has led to the creation of artificial dichotomies between status or belief on one side and behavior on the other-with the former considered inviolate and the latter receiving little or no protection. ${ }^{73}$

Of course, such distinctions are little more than legal fictions designed to shield a court or other decision maker from the unenviable task of adjudicating difficult issues in an open and honest fashion. In reality, both religious belief and sexual orientation are characteristics so intimately connected with human behavior that they cannot be disentangled. Indeed, it is hardly enough to say that identity defined by either naturally involves conduct or a propensity to engage in a certain type of behavior: both can be seen as a way of life, and it is the lifestyle that creates the identity and vice versa. Hence, when one is dealing with the conduct that defines the identity, whether it be same-sex hand-holding or

7 See William P. Marshall, The Inequality of Anti-Establishment, 1993 BYU L Rev 63, 69; Eisgruber and Sager, $61 \mathrm{U}$ Chi L Rev at 1256-57 (cited in note 66).

72 More specifically, formal equality under the Free Exercise Clause and a variation on substantive equality under the Establishment Clause that allows, even insists on, government endorsement of secularism and irreligious beliefs while strictly prohibiting any attempt by religionists to use the political processes to reinforce their self-identity. See Marshall, 1993 BYU L Rev at 68-71.

${ }^{73}$ For an example of this dichotomy in the religion context, see Reynolds, 98 US at 166; text accompanying notes 11-14. For a similar discussion in the sexual orientation realm, see text accompanying notes $86-88$. 
the sacramental use of peyote, one is dealing with the status or identity itself.

\section{Exiled from Public Discourse}

Another parallel between sexual orientation and religion, and one that is particularly significant, is that both are generally accepted as intensely personal matters. Many conclude from this that sexual and religious expression are not appropriate topics for public discourse. This public/private argument underlies many of the limitations on individual expression in these areas.

Several commentators have noted the way religion is privatized and marginalized in contemporary society. ${ }^{74}$ Indeed, the Supreme Court has declared on more than one occasion that "[t]he Constitution decrees that religion must be a private matter for the individual, the family, and the institutions of private choice. ${ }^{775}$ Whether intended or not, the implication is that religion has little or nothing to offer to the public sphere. ${ }^{76}$

Proponents of protecting sexual orientation have similarly argued that public/private distinctions have led to the expulsion of sexual expression, particularly gay and lesbian expression, from the public realm. ${ }^{77}$ Most prominent is the military's current "don't ask, don't tell" policy on homosexuality, although similar "no promo homo"78 policies have been in place in various areas of public life for decades. ${ }^{79}$

\section{Similar Group Characteristics}

In addition to parallels on the level of the individual, religious groups, particularly religious minorities, have many of the same group characteristics as gays and lesbians. ${ }^{80}$ These include

74 See, for example, Michael W. McConnell, "God is Dead and We Have Killed Him!": Freedom of Religion in the Post-Modern Age, 1993 BYU L Rev 163, 164-66; Stephen L. Carter, The Culture of Disbelief: How American Law and Politics Trivialize Religious Devotion (Basic Books, 1993).

${ }^{75}$ Lemon v Kurtzman, 403 US 602, 625 (1971). See also Grand Rapids School District $v$ Ball, 473 US 373, 398 (1985) (quoting Lemon); Larkin v Grendel's Den, Inc., 459 US 116, 126 (1982) (same); Mueller v Allen, 463 US 388, 416 (1983) (same).

${ }_{76}$ See Carter, Culture of Disbelief at 25 (arguing that contemporary culture pushes religious individuals to keep their beliefs and particularly their unusual practices to themselves).

77 See Nan D. Hunter, Identity, Speech, and Equality, 79 Va L Rev 1695, 1702-16 (1993).

${ }^{78}$ For a definition of "no promo homo" rules and a discussion of the term and its development, see id.

79 Id.

so Focusing some attention on the group characteristics of religion makes sense for at 
a history of discrimination and a lack of political power. Most significantly, unlike race, gender, and ethnicity, membership in a group defined by religion or sexual orientation is based on criteria that, for the most part, are not visible to others. As a result, the ability to express openly one's membership in the group is essential to the group's continued vitality. Because, as discussed above, the criteria that identifies one as a member of such a group is so often intimately bound up with conduct or behavior of some kind, the ability to openly practice this conduct is essential to identification with the group.

\section{Developments In SeXual Orientation Theory}

\section{A. Bowers $v$ Hardwick and its Aftermath}

Recent developments in sexual orientation theory are best understood as a reaction to the current state of the law. In many respects, the Supreme Court's decision in Bowers $v$ Hardwick $^{81}$ has defined the nature of the current debate. Prior to Hardwick, most advocates saw the newly articulated penumbral right to privacy as the best hope of securing constitutional protections for homosexual activities. However, after the Court's decision, proponents of gay and lesbian rights found themselves searching for a new constitutional provision on which to base protection.

Perhaps the most distinctive feature of Hardwick was the way in which Justice White, writing for the Court, framed the issue: "whether the Federal Constitution confers a fundamental right upon homosexuals to engage in sodomy. ${ }^{182}$ The Court's attention was focused solely on the act of homosexual sodomy. Some commentators have argued that this focus tends to equate homosexual orientation with the act of sodomy, to the exclusion of other aspects of homosexual identity. ${ }^{83}$ As will be explored

least two reasons. First, a religious life includes not only a profound connection to a divinely inspired way of life, but also a profound connection to the community defined by allegiance to that way of life. See Note, Reinterpreting the Religion Clauses: Constitutional Construction and Conceptions of the Self, 97 Harv L Rev 1468, 1472-75 (1984); Francis Mark Gedicks, Toward a Constitutional Jurisprudence of Religious Group Rights, 1989 Wis L Rev 99, 106-15; Pepper, 1993 BYU L Rev at 42 (cited in note 63). Second, although their claims are typically adjudicated under the religion clauses, religious minorities are at least potentially a suspect class under United States $v$ Carolene Products Co., 304 US 144,152 n 4 (1938).

B1 478 US 186 (1986).

52 Id at 190. The problem with the Court's framing of the issue was that the statute interpreted was a general ban on all sodomy regardless of the gender or sexual orientation of the participants. Id.

${ }_{3}$ See, for example, Janet E. Halley, Reasoning About Sodomy: Act and Identity In 
below, such an act-centered focus has had important ramifications in the development of sexual orientation theory and the divorcing of homosexual identity from homosexual conduct.

In the aftermath of Hardwick, the federal courts divided over what has become known as the status/conduct debate, with most courts ruling that discrimination on the basis of sexual orientation could not be subject to heightened scrutiny under the Equal Protection Clause because it was constitutionally permissible under Hardwick for a state to criminalize sodomy, and participation in sodomy defined homosexuals as a class. ${ }^{84}$ Left without a privacy-based defense of homosexual conduct, advocates argued that sexual orientation was first and foremost a status, not contingent on any particular conduct. Thus, they argued for protection by analogizing to the traditionally recognized suspect classes of race and gender. ${ }^{85}$ However, such analogies, by failing to recognize that sexual orientation, unlike the traditional suspect classes, has at its core an important element of conduct, have only exacerbated the artificial status/conduct dichotomies.

\section{B. "No Promo Homo" and the Status/Conduct Debate}

Many proponents of homosexual rights find themselves constrained into divorcing homosexual status from homosexual conduct. This is so partly because of the way the Court framed the Hardwick holding and partly because of the forced analogies to race and gender. The ban on military service by lesbians, gay men, and bisexuals is a particularly rich, although by no means the only, example of how such artificial distinctions interact with the concepts of identity, equality, and expression.

First, the rhetoric of the debate over the military ban mirrors the debate about status and conduct generally. President Clinton framed his position against the existing exclusionary rule as opposition to discrimination "based solely on status." In response, congressional opponents like Senator Sam Nunn argued

and After Bowers v. Hardwick, 79 Va L Rev 1721, 1734-45 (1993).

84 See generally Nan D. Hunter, Life After Hardwick, 27 Harv CR-CL I Rev 531 (1992) (discussing in detail both the origins of the status/conduct distinctions and the gaps that have arisen in this discourse).

${ }_{85}$ See, for example, Janet E. Halley, The Politics of the Closet: Towards Equal Protection for Gay, Lesbian, and Bisexual Identity, 36 UCLA L Rev 915 (1989). See also Note, The Constitutional Status of Sexual Orientation: Homosexuality as a Suspect Classification, 98 Harv L Rev 1285 (1985).

${ }_{86}$ See Michael R. Gordon, Hints of Gay-Ban Compromise in Senate, NY Times A18 (Mar 29, 1993). 
that homosexual status could not exist independent of homosexual sex acts. ${ }^{87}$

Second, the military has conceded that homosexual identity does not affect a soldier's ability to perform in the military, except to the extent the identity is expressed to others. General Colin Powell, then Chairman of the Joint Chiefs of Staff, and others testified that gays and lesbians had always served in the military, and that their presence did not cause any problems as

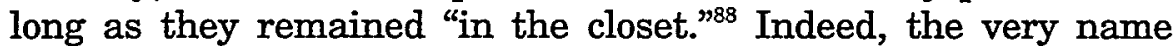
given to the military's policy, "don't ask, don't tell," reveals that it is designed to regulate expression of some kind.

Finally, only public declarations of homosexuality could trigger enforcement of the ban, whether through statements or symbolic acts. Thus, same-sex hand-holding or marriage, two public expressions of sexual identity, are grounds for discharge unless the individual can prove that he or she has no propensity or intent to engage in homosexual sex. By contrast, hand-holding in private or a private commitment to a lifelong homosexual relationship does not trigger investigation or penalty.

C. Identity, Expression, and Equality: The Concept of Identity Speech

Commentators are increasingly recognizing the expressive dimension of restrictions on gay and lesbian "conduct." As a result, several are arguing for protection under the First Amendment's Free Speech Clause. ${ }^{89}$ This view stresses that our First Amendment tradition is committed to assuring a safe haven for individuals to develop and then to express their ideas, feelings, and emotions in the manner that best suits them. ${ }^{90}$ In oth-

${ }^{87}$ See Debbie Howlett, Senator Fears Gay Disaster, USA Today 10A (June 1, 1993).

8 See Fiscal Year 1993 Defense Budget, Hearing before the House Committee on the Budget, 102d Cong, 2d Sess 1, 45 (1992). Responding to the question of whether there was any evidence of behavior problems as a result of the longstanding presence of gays and lesbians in the military, General Powell replied:

No, because as a matter of fact they have kept, so-called in the closet. It is quite a different thing when it is openly practiced or openly known throughout the force and within the units. I think it makes very difficult management problems. Id.

ह9 See, for example, David Cole and William N. Eskridge, Jr., From Hand-Holding to Sodomy: First Amendment Protection of Homosexual (Expressive) Conduct, 29 Harv CR-CL L Rev 319 (1994) (developing a First Amendment basis for protecting public and private homosexual acts); Hunter, $79 \mathrm{Va} \mathrm{L}$ Rev at 1696, 1716-19 (cited in note 77) (exploring the expressive nature of homosexual practices).

${ }^{50}$ For an example of judicial recognition of this developmental function, see Cohen $v$ 
er words, certain forms of expression are preserved from state manipulation not just for their utility to social organization but because of their importance to human development. Foremost among these First Amendment approaches is the concept of "identity speech."

The theory of identity speech combines two powerful aspects of sexual orientation arguments: the fundamental role sexual orientation plays in defining identity and the expressive nature of the "conduct" involved. Publicly declaring one's status or membership in a group that is central to one's identity, even if that expression takes the form of openly engaging in the activities that define group membership, is at the core of free speech. As one commentator put it, "[s]elf-representation of one's sexual identity necessarily includes a message that one has not merely come out, but that one intends to be out-to act on and live out that identity." ${ }^{\prime \prime 1}$ Indeed, the argument goes, given the injury suffered by an individual when such self-identifying expression is prohibited, it should be among the most protected forms of speech.

"Identity" in the theory of identity speech is a complex concept. It transcends the dialogic rhetoric of status and conduct that typically dominates discussions in this area and encompasses explanation and representation of the self. Thus, the gap between status and conduct is bridged by an emphasis on the expressive right to represent one's status or membership in a group that is itself defined largely by the type of activities in which its members are engaged.

The fact that the activities at issue in the sexual orientation area, ranging from public hand-holding and kissing to private sodomy, might only be symbolic of ideas and attitudes rather than literal statements of position in the public debate about

California, 403 US 15, 24 (1971):

The constitutional right of free expression is ... designed and intended to remove governmental restraints from the arena of public discussion, ... in the hope that use of such freedom will ultimately produce a more capable citizenry and more perfect polity and in the belief that no other approach would comport with the premise of individual dignity and choice upon which our political system rests.

See also Whitney $v$ California, 274 US 357, 375 (1927) (Brandeis concurring) ("Those who won our independence believed that the final end of the State was to make men free to develop their faculties."); Roberts v United States Jaycees, 468 US 609, 619 (1984) ("Protecting [highly personal relationships] from unwarranted state interference therefore safeguards the ability independently to define one's identity that is central to any concept of liberty.").

${ }_{91}$ Hunter, 79 Va L Rev at 1696 (cited in note 77). 
sexuality does not necessarily diminish their expressive value. "Public" debate has never been limited solely to such obvious forms of speech as books, articles, speeches, and picket signs; it has always included symbolic gestures such as dancing, visual art and advertising, public demonstrations, clothing, and physical conduct. $^{92}$

Advocates of this identity speech approach generally track the Supreme Court's two-step method of determining the constitutionality of statutes regulating expressive conduct. This analysis first asks whether the conduct involved is expressive: whether it is intended to communicate and whether it is likely to be understood by an audience as communicative. ${ }^{93}$ Given the wide range of activities that carry some form of expressive content, it is not surprising that this first inquiry has a very low threshold.

The second step in the analysis of expressive conduct is the critical one: it asks whether the government's regulatory purpose is related to the conduct's expressive elements. ${ }^{94}$ Thus, when Texas sought to outlaw flag burning, the Court found that the state's primary interest was in suppressing the messages associated with such conduct and subjected the law to heightened First Amendment scrutiny. ${ }^{95}$ As the Court put it, the determinative question was whether the state's interest in banning the conduct was "related to the suppression of expression." By contrast, when protesters seeking to dramatize the plight of the homeless by sleeping in Lafayette Park challenged the National Park Service's prohibition on sleeping in public parks, the Court, applying minimal scrutiny, upheld the ban. ${ }^{97}$ It found that the government's interest in preventing sleeping in parks was based on the safety and upkeep of parks and had nothing to do with the message the protesters sought to communicate. ${ }^{98}$

Although conceding that private homosexual conduct does not directly contribute to public debate in the way that public affirmations of homosexuality do, those arguing for protection of gays and lesbians on First Amendment grounds nonetheless

92 See note 58.

${ }_{93}$ See Texas $v$ Johnson, 491 US 397, 404-05 (1989); Spence $v$ Washington, 418 US 405, 409-10 (1974).

94 See United States $v$ Eichman, 496 US 310, 315-18 (1990); dohnson, 491 US at 407.

See also R.A.V. $v$ City of St. Paul, 112 S Ct 2538, 2544 (1992).

${ }^{95}$ Johnson, 491 US at 407, 410.

96 Id at 407.

${ }^{97}$ Clark v Community for Creative Non-Violence, 468 US 288, 289 (1984).

${ }^{93}$ Id at 297-99. 
assert that such private activities play an indispensable part in shaping the public debate. Because homosexuals "explore and develop their sexual identity through private sexual conduct, that private conduct is critical to their ability to take part as lesbians, gay men, and bisexuals in public life." ${ }^{\prime 99}$ The primary effect, then, of such "no promo homo" legal mechanisms as the military exclusion and state sodomy laws is to keep homosexuality "in the closet," both hidden from the public and incapable of contributing to public discourse and politics.

\section{TOWARD A FULLER VISION OF RELIGIOUS EXERCISE}

This Comment has argued that courts systematically undervalue the rights of religious minorities by adopting an incomplete understanding of religious exercise as the starting point of their free exercise analysis. Consequently, whatever balancing standard is being applied, the outcome is inevitably skewed in favor of the state's interest. This is particularly true in the case of a religious minority whose practices are sufficiently out of the mainstream to make it difficult for judges to identify their practices as religious worship and easy to doubt the depth and sincerity of the convictions behind them. By adopting an approach similar to that of identity speech espoused in the sexual orientation field, advocates of a more vibrant Free Exercise Clause can provide courts with a fuller vision of religious liberty and provide a more coherent way of articulating the injury that occurs to an individual when her free exercise rights are infringed.

A. Applying Identity Speech Concepts to Religious Claims: Revisiting Goldman $v$ Weinberger

This Subsection re-examines the Court's decision in Goldman $v$ Weinberger ${ }^{100}$ in order to illustrate the application of "identity speech" analysis to free exercise claims. The Goldman Court rejected an Orthodox Jewish Air Force officer's claim that the Free Exercise Clause gave him a constitutional right to wear a yarmulke as part of his military attire. The case provides a useful analysis for present purposes in part because it involves the military context, where most of the details of the identity speech arguments of gay rights advocates have been developed.

s9 Cole and Eskridge, 29 Harv CR-CL L Rev at 329 (cited in note 89).

100 475 US 503 (1986). 
Before reworking Goldman under an identity speech approach, certain differences in the analysis between sexual orientation and religion should be identified. First, unlike claims of discrimination on the basis of sexual orientation, which typically seek to void an entire policy or law, claims of religious exercise generally seek only to exempt a religious minority from an otherwise neutral rule.

Second, because the remedy sought is typically narrower-a small exception rather than voiding the entire rule-the otherwise necessary showing that the state's purpose in regulating the conduct relates to its expressive element is less critical. Instead, the proper question is whether there is a less restrictive alternative the state could adopt to carry out its legitimate interests without infringing on the religious exercise of the minority. Similarly, because the religious claimant is not typically asking for the policy or law as a whole to be declared unconstitutional, the proper application of a compelling state interest standard asks not if the state has a compelling interest in propagating or enforcing the rule as a whole, but if it has a compelling interest in denying the exemption. ${ }^{101}$ Thus, the narrower nature of the religious exemption claim requires a narrower framing of the state's interest. Such proportionality is vital to the proper application of any balancing standard adopted by the Court.

As for the interests at stake in Goldman, the military had two principal arguments. First, the military argued that it has a strong interest in promoting uniformity of appearance, which in turn promotes esprit de corps and obedience to authority. ${ }^{102}$ Second, it claimed that if it granted a yarmulke exception to Jewish servicemen, which both sides seemed to concede was "unobtrusive," it would soon be flooded with similar claims from various other religious groups; and while a yarmulke may not seem obtrusive to a Jew, "neither does a turban to a Sikh, a saffron robe to a Satchidananda Ashram-Integral Yogi, [or] dreadlocks to a Rastafarian." ${ }^{103}$ This is, of course, the classic slippery slope argument that is repeatedly seen in religious exemption cases. ${ }^{104}$

${ }^{101}$ See Yoder, 406 US at 221.

${ }_{102}$ Goldman, 475 US at 408-09.

103 Id at 519 (Brennan dissenting).

${ }_{104}$ For a discussion of the "slippery slope" argument in religious exemption cases, see Ira C. Lupu, Where Rights Begin: The Problem of Burdens on the Free Exercise of Religion, 102 Harv L Rev 933, 947 (1989). 
However, Justice Stevens's concurring opinion adds a different and more interesting twist to the standard parade-ofhorribles argument. Uniformity, he says, has a more important dimension: "[i]t is the interest in uniform treatment for the members of all religious faiths." 105 For Justice Stevens, basing the determination of permissible religious attire on the "neutral, completely objective standard" of visibility is the superior rule, even if it forecloses a multitude of religious accommodations that would have no significant adverse impact on the military's expressed interests of protecting esprit de corps and obedience to authority. ${ }^{106}$ This view pushed neutrality to its logical extreme: because some religious minorities might want to wear "so extreme, so unusual, or so faddish an image," military officials will be forced into denying some religious apparel based on such nonneutral and nonobjective criteria as "neat and conservative"; to avoid this nonneutral result, all visible religious attire must be banned, regardless of how religiously compelled or how inoffensive to military interests. ${ }^{107}$

By grounding his argument in the values of "neutrality" and "objectivity," Justice Stevens makes his position sound quite persuasive. There are, however, two main flaws in his approach, one empirical, and the other principled. Justice Blackmun makes the empirical challenge in his dissent: "[t]he Air Force simply has not shown any reason to fear that a significant number of enlisted personnel and officers would request religious exemptions that could not be denied on neutral grounds." 108 Interestingly, shortly after the Court's decision, Congress revised the military's dress code to allow for religious apparel so long as it did not "interfere with the performance of the member's military duties" and is "neat and conservative." 109 In the wake of this legislative action, the military does not appear to have been swamped with Satchidananda Ashram-Integral Yogi servicemen clamoring for their rights to wear saffron robes, nor has its ability to respond to conflicts around the globe been impaired.

${ }^{105}$ Goldman, 475 US at 512 (Stevens concurring).

106 Id at 513.

107 Id at 512-13.

${ }^{109}$ Id at 527 (Blackmun dissenting).

109 Pub L No 100-180, 101 Stat 1086, codified at 10 USC $\S 774$ (1988). The "neat and conservative" standard follows Justice Brennan's suggestion and is modeled after the military's standard for the wearing of jewelry. See Goldman, 475 US at 520 (Brennan dissenting), quoting AFR 35-10, II 1-12b(1)(b) (1978). 
The concept of identity speech, however, provides the groundwork for a more principled challenge to the visibility standard Justice Stevens supported. The military's decision to draw the line at visible manifestations of religious apparel and its concern over the way others would interpret such apparel illustrates that what the military was really attempting to regulate, or at least what it had the effect of regulating, was the public expression of a service member's religious identity. ${ }^{110}$ One doubts whether the Court would have adopted such a deferential stance if the regulation at issue prohibited service members from openly discussing their religious affiliations with other service members or civilians. Clearly, such a regulation could be portrayed as furthering the important interests of promoting uniformity, esprit de corps, and obedience to authority. Yet the visibility standard approved by the Court has much the same effect as a ban on open discussion, although admittedly to a lesser degree.

Certainly, the wearing of religious apparel as part of one's religious practice and worship qualifies as "expressive conduct" for purposes of the First Amendment. ${ }^{111}$ Equally clear is that the military's selection of the visibility standard was related to the expressive element of the conduct being regulated. Thus, at the very least, Goldman qualifies as a "free exercise plus" case under Smith. ${ }^{112}$ Yet there was no discussion of either free speech rights or the expressive element of the religious exercise involved.

Applying "identity speech" rationales to expressive religious practices, such as the wearing of yarmulkes by a Jewish serviceman, also has several more subtle implications. ${ }^{113}$ First, penalizing the self-identifying religious practices of religious minorities effectively nullifies any protection under equality principles. In this instance, it is realistically impossible to separate religious practice from status. Such a penalty makes the promise of equali-

110 Indeed, the only justifications the government gave for its visibility test were based on what visible religious apparel communicates to others. What made Goldman's wearing of a yarmulke objectionable to the military, while less visible attire (such as sacred Mormon undergarments) was not, was that it sent a message to all who came in contact with him that he was a member of a particular religion. Rather than just a serviceman, he was a Jewish serviceman, creating an alleged subversion of uniformity and espirit de corps.

111 Compare with the expressive conduct cases reviewed in note 58.

112 See text accompanying note 40.

113 The analysis here is patterned after that made by Nan Hunter in the area of military regulation of homosexual conduct. See Hunter, $79 \mathrm{Va} L \mathrm{Rev}$ at 1718-19 (cited in note 77). 
ty a sham, effectively denying religious protection to anyone devout enough to openly practice his or her religion.

Second, suppression of self-identifying religious practices leads to a compelled falsehood, a violation of the principle that an individual has the right not to speak as well as to speak. ${ }^{114}$ Given the current baseline of exiling religion and religious practices from public life, in the absence of religious expression to the contrary, most persons in the public realm will be presumed to be secularists, or in the alternative, mainstream Protestants. To compel silence, then, is in effect to force religious minorities who are neither to lie.

Lastly, like forced speech, the collective, communal impact of forced silence amounts to more than an accumulation of violations of individual integrity. It creates a form of state orthodoxy. ${ }^{115}$ If expressing religious practices can communicate ideas and viewpoints that dissent from majoritarian or official norms, then the silencing of certain religious identities has the opposite, totalitarian effect of enforcing conformity. In that sense, religion generally, and minority religions in particular, are not merely, or either, status or conduct. They are also, independently, ideas. In this sense, it is the role of religion in the realm of public discourse itself that is at stake in such battles.

B. Limitations on the Application of Identity Speech Analysis to Religious Claims

In arguing for a focus on the expressive nature of the conduct involved, care must be given not to overemphasize the expressive function of religious exercise. Although this Comment argues that most religious practices are deeply symbolic and expressive in nature, particularly in their role of defining and representing individual identity, that current judicial standards fall woefully short of recognizing these expressive elements, and that an approach that emphasizes these excluded elements would provide a more complete understanding of the free exercise right, it does not argue that we should collapse religious liberty into traditional speech analysis.

Although such proposals have been made, ${ }^{116}$ free exercise

114 See West Virginia State Board of Education v Barnette, 319 US 624, 642 (1943) (holding that West Virginia could not require that Jehovah's Witness school children participate in the pledge of allegiance). See also note 52.

115 See note 52.

116 See, for example, William P. Marshall, Solving the Free Exercise Dilemma: Free 
and free speech rights are sufficiently distinct that the wholesale adoption of traditional speech analysis into the free exercise realm would ultimately be injurious to religious liberties. ${ }^{117}$ First, traditional speech protections are often seen as instrumental in nature - concerned primarily with the discovery of truth in the marketplace of ideas-while religious protections are generally more concerned with the dignitary and autonomy interests of the individual. ${ }^{118}$ Furthermore, at times this dignitary or developmental function is treated as a secondary attribute of free speech, one that is more easily outweighed by important state interests. ${ }^{119}$ Likewise, speech on matters of "public concern" is typically more protected than speech regarding purely private interests. ${ }^{120}$

Second, and more importantly, the First Amendment specifically singles out religion among all the various belief systems and world views as entitled to special protection, while traditional speech doctrines provide no such favored status for religiously expressive conduct. The inclusion of religion in the First Amendment demonstrates that religion is an independent and unique factor in our political-legal system. Thus, application of the neutrality norms of free speech to the religion clauses seems clearly anomalous. ${ }^{121}$ The Free Exercise Clause grants religious belief systems a different constitutional status than nonreligious belief systems. The Constitution is no more neutral in this respect than

Exercise as Expression, 67 Minn L Rev 545, 546-47 (1983) (arguing that Free Exercise Clause protections should be limited to be consistent with the entire First Amendment's emphasis on protecting communicative activities); Pepper, 1981 Utah L Rev at 367-68 (cited in note 18).

117 For a similar view, see Michael W. McConnell, Accommodation of Religion: An Update and $a$ Response to the Critics, 60 Geo Wash L Rev 685, 719-20 (1992) (rejecting an approach collapsing free exercise into traditional speech analysis).

118 In part, this Comment argues that traditional speech concerns include the dignitary or developmental interests of the individual and that much of the expressive element of religious devotion could be considered core political speech.

119 See Rodney A. Smolla, Smolla and Nimmer on Freedom of Speech: A Treatise on the First Amendment $\$ 2.03$ (Matthew Bender, 1994) (noting that the speech interest "may often be found subordinate to the anti-speech interest where only the self-fulfillment . . . function is served by the speech"). See also Connick v Myers, 461 US 138, 146 (1983) ("When employee expression cannot be fairly considered as relating to any matter of political, social, or other concern to the community, government officials should enjoy wide latitude in managing their offices, without intrusive oversight by the judiciary in the name of the First Amendment.").

${ }^{120}$ See Dun \& Bradstreet Inc. v Greenmoss Builders, 472 US 749, 758-59 (1985). Note, however, that if properly framed, many expressive elements of private religious practice could be deemed to touch on matters of public concern.

121 See text accompanying notes 66-70. 
it is neutral between expressive and nonexpressive conduct or property and nonproperty interests. ${ }^{122}$ The same is true of the Establishment Clause. Government entanglement with secular belief systems does not implicate the same constitutional concerns as entanglement with religious belief systems. ${ }^{123}$

In addition, the application of identity speech rationales to free exercise jurisprudence does not change the nature of Establishment Clause concerns. Thus, a large portion of decisions remain unaffected. However, a fuller vision of religious exercise might influence a court's balancing of establishment and free exercise interests, particularly if the balance is a close one.

\section{CONCLUSION}

In the discussion over the proper level of scrutiny courts should use in determining free exercise claims, not enough attention has been paid to the meaning of religious exercise itself. Current and past case law illustrates that the Supreme Court has adopted an incomplete understanding of religious exercise that has had a disparate impact on religious minorities. Refocusing the Court's attention on the deeply symbolic and expressive nature of religious devotion and the fundamental role such devotion plays in defining individual and group conceptions of identity provides the basis for a fuller vision of the free exercise right and a more systematic way of articulating the injury that occurs to an individual whose free exercise rights are infringed. In the process, it should bring the Court's free exercise jurisprudence more into line with the realities of religious devotion and experience.

122 See, for example, Yoder, 406 US at 215-216 (granting an exemption to compulsory attendance laws for Amish claimants, but noting that a similar claim based on nonreligious philosophical or personal grounds would be denied).

${ }_{123}$ See Smith v Board of School Commissioners, 827 F2d 684, 694-95 (11th Cir 1987) (holding that selection of school textbooks that "advanced" secular humanism did not violate Establishment Clause because it had secular purpose and "neutral" effects). 